Original Article

\title{
Horismenus camobiensis (Hym.: Eulophidae), a new hyperparasitoid of Cotesia invirae (Hym.: Braconidae) in Opsiphanes invirae (Lep.: Nymphalidae) pupae
}

\author{
Horismenus camobiensis (Hym.: Eulophidae), um novo hiperparasitóide de Cotesia \\ invirae (Hym.: Braconidae) em pupas de Opsiphanes invirae (Lep.: Nymphalidae)

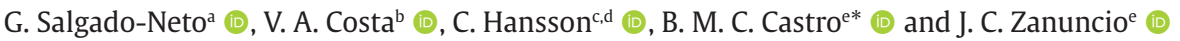 \\ ániversidade Federal de Santa Maria - UFSM, Departamento de Defesa Fitossanitária, Pós-graduação em Agronomia, Santa Maria, RS, Brasil \\ 'DInstituto Biológico, Centro Avançado de Pesquisa em Proteção de Plantas e Saúde Animal, Campinas, SP, Brasil \\ cLund University, Museum of Biology (Entomology), Lund, Sweden \\ 'Natural History Museum, London, United Kingdom \\ 'Universidade Federal de Viçosa - UFV, Departamento de Entomologia/BIOAGRO, Viçosa, MG, Brasil
}

\begin{abstract}
Horismenus camobiensis sp. nov. (Hymenoptera: Eulophidae), is described based on morphological, molecular and ecological data; this new species of chalcid wasp acts as hyperparasitoid of Opsiphanis invirae (Hübner, 1818) (Lepidoptera: Nymphalidae) in its parasitoid Cotesia invirae Salgado-Neto and Whitfield, 2019 (Hymenoptera: Braconidae). Diagnoses with morphological and molecular characters and illustrations are provided.

Keywords: Chalcidoidea, Entedoninae, taxonomy.

Resumo

Horismenus camobiensis sp. nov. (Hymenoptera: Eulophidae) é descrita com base em dados morfológicos, moleculares e ecológicos; esta nova espécie Chalcididae atua como hiperparasitoide de Opsiphanis invirae (Hübner; 1818) (Lepidoptera: Nymphalidae) em pupas de seu parasitoide Cotesia invirae Salgado-Neto and Whitfield, 2019 (Hymenoptera: Braconidae). Caracteres diagnósticos morfológicos e moleculares e ilustrações de H. camobiensis são fornecidos.
\end{abstract}

Palavras-chave: Chalcidoidea, Entedoninae, taxonomia.

\section{Introduction}

Horismenus Walker, 1843, with about 420 species, is one of the largest Eulophidae groups and its species act as primary or secondary parasitoid of insects and arachnids (Noyes, 2018; Morales-Silva et al., 2019), mainly in tropical America (Hansson, 2009). Most records mention Horismenus as primary parasitoids, but at least 14 of its species act as secondary parasitoids of Braconidae, mainly of Microgastrinae species (Hansson et al., 2014; Pikart et al., 2015). Thirty-nine species of Horismenus are reported in Brazil (Hansson, 2009; Hansson et al., 2014; Pikart et al., 2015).

Cotesia Cameron, 1891 (Braconidae: Microgastrinae) is one of the largest genus of microgastrine wasps with 300-400 described species (Shaw and Huddleston, 1991; Yu et al., 2016). There are records of Cotesia specimens obtained from Opsiphanes invirae (Hübner, 1818) (Lepidoptera: Nymphalidae) larvae that feed on palm trees in in Brazil, Peru and Venezuela (Yu et al., 2016), amongst them, C. invirae (Salgado-Neto and Whitfield, 2019).

Opsiphanes invirae caterpillars damage palm foliage throughout Central America and the northern South America (Lepesme, 1947), including the Amazonian region (Sefer, 1961) to southern Brazil (Silva et al., 1968; Ferreira et al., 1998). Brachymeria costalimai (Delvare et al., 2017), Conura morleyi (Ashmead, 1904), Conura maculata (Fabricius, 1787), Conura nigrifrons (Cameron, 1884),(Hym.: Chalcididae) and Chetogena scutellaris (Van der Wulp, 1890) (Dip.: Tachinidae), C. invirae (Salgado-Neto et al., 2019) and Xanthozona melanopyga (Wiedemann, 1830) (Dip.: Tachinidae) are the known natural enemies of 0 . invirae (Wiedemann, 1830; Townsend, 1939; Silva et al., 1968).

Four Eulophidae species have been reported as hyperparasitoids in pupae of Cotesia: Oomyzus sokolowskii (Kurdjumov, 1912), Horismenus opsiphanis (Schrottky,

*e-mail: barbaramcastro@hotmail.com

Received: February 22, 2021 - Accepted: October 30, 2021 
1909), an undescribed species of Aprostocetus Westwood, 1883 (Ashmead, 1904), and an undescribed species of Horismenus Walker, 1843 (Salgado-Neto and Di Mare, 2010, Salgado-Neto et al., 2019). Tritrophic interaction between O. cassina Felder and Felder (Lep.: Nymphalidae) in C. cassina (Salgado-Neto, Vásquez and Whitfield, 2021) pupae and an undescribed species of Horismenus Walker, 1843 (Eulophidae) was recently observed in Colombia (Salgado-Neto et al., 2021).

Here in, Horismenus camobiensis sp. nov., a hyperparasitoid of 0 . invirae, through $C$. invirae, is described and illustrated.

\section{Material and Methods}

The studied Horismenus specimens were reared from C. invirae, which in turn parasitized 0 . invirae caterpillars on palm trees (Salgado-Neto and Di Mare, 2010; SalgadoNeto, 2013; Salgado-Neto et al., 2019). Specimens were examined through a Leica M165C stereomicroscope (Leica Microsystems GmbH, Wetzlar, Germany). Color images were taken with a Leica DFC 420 digital camera attached to this Leica stereomicroscope and illuminated with a LED dome (Kerr et al., 2008). The final extended-focus image was combined with Leica Application Suite v3.8. SEM micrographs of uncoated holotype and paratype specimens were taken with a Quanta 250 scanning electron microscope (FEI Company, Hillsboro, USA), at low vacuum mode.

The molecular-specific characterization of the new species was based on its mitochondrial gene Cytochrome Oxidase I (COI). A fragment of approximately 460 bp of this gene was amplified with the primer pair
COI-F (5'-GATTTTTTGGKCAYCC MGA AG-3') and COI-R (5'CRAATACRGCTCCTA TWG ATAAWAC-3') (Gusmão et al., 2010). The DNA was extracted from one specimen with the GenElute Mammalian Genomic DNA Miniprep Kit (Sigma-Aldrich ${ }^{\circledR}$ ) following the manufacturer protocol. The product was amplified via Polymerase Chain Reaction (PCR) according to the following schedule: $94^{\circ} \mathrm{C}$ for 2 minutes, 40 cycles at $94^{\circ} \mathrm{C}$ for 30 seconds each, $54^{\circ} \mathrm{C}$ for 30 seconds, $72{ }^{\circ} \mathrm{C}$ for 40 seconds and $72{ }^{\circ} \mathrm{C}$ for 4 minutes. The PCR product was purified using polyethylene glycol precipitation (PEG) (Schmitz and Riesner, 2006) and sequenced using the Big Dye 3.1 reagent (Life Technologies ${ }^{\circledR}$ ) and $3500 \mathrm{xL}$ automatic sequencer (Life Technologies ${ }^{\circledR}$ ).

\subsection{Molecular identification}

Horismenus camobiensis sp. nov. was characterized by sequencing the mtDNA COI gene of seven specimens from Brazil. The consensus sequences from Brazil showed one SNP (Single Nucleotide Polymorphisms) located at $280 \mathrm{bp}$ from the alignment between the cladogram data sets and identified as a pyrimidine substitution (T/C). The NCBI/Genbank deposit generated the accession number MK455796 for Brazil. The cladogram (Figure 1) was reconstructed, based on analyses of the COI region performed by the General Time Reversible (GTR) nucleotide substitution model, with gamma distributed with invariant sites; parameters for partial exemption (95\%) were estimated as the best substitution model using MEGA 5.0 software (Tamura et al., 2011). The largest possible number of comparatives accessed from those deposited in NCBI was included to perform the cladogram analyses.

A phylogenetic dendrogram (Figure 1) was obtained for the Horismenus spp. from the sequences deposited in the GenBank. Evolutionary distances were calculated

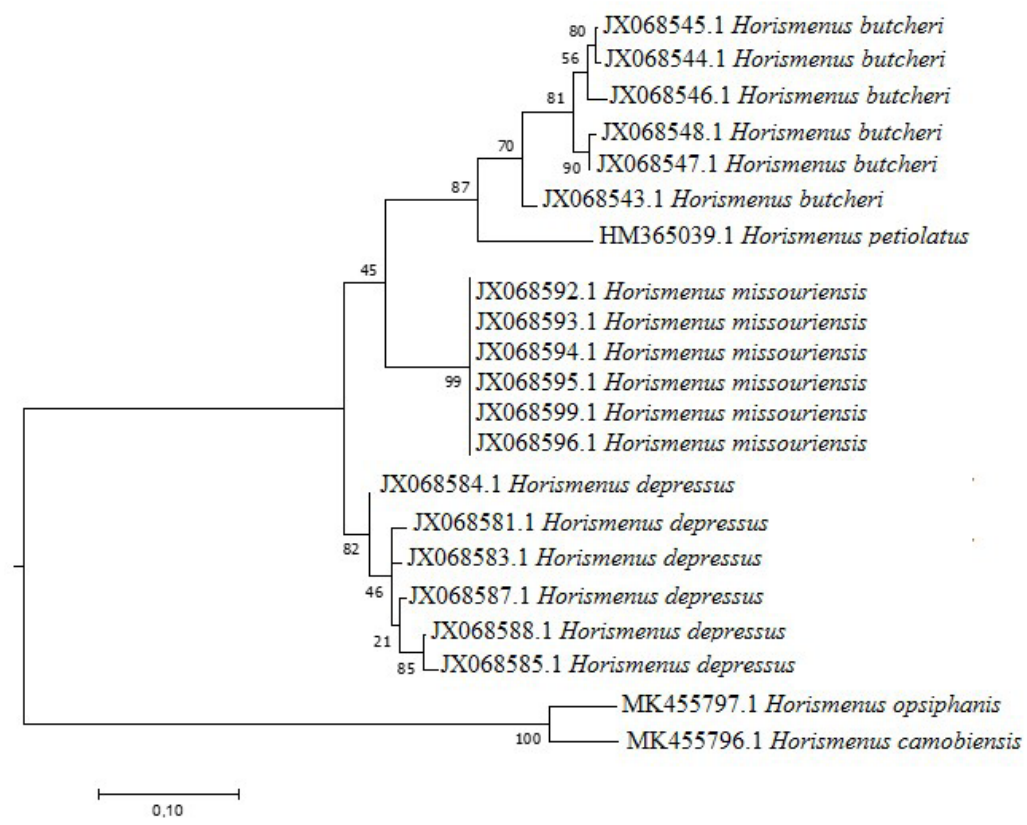

Figure 1. Cladogram of the studied species of Horismenus (Hymenoptera: Eulophidae) inferred from partial mtDNA COI gene region sequences, using Maximum Likelihood analysis. 
and evolutionary history inferred with the Maximum Likelihood Method (Tamura and Nei, 1993).

The molecular-specific characterization of the new species was performed. A fragment of approximately $460 \mathrm{bp}$ of this gene was amplified with the primer pairs COI-F (5'-GATTTTTTGGKCAYCCMGAAG-3') and COI-R (5'CRAATACRGCTCC TATWGATAA WAC-3') (Gusmão et al., 2010). The DNA of this fragment was extracted from one specimen with the GenElute Mammalian Genomic DNA Miniprep Kit (Sigma-Aldrich $\left.{ }^{\circledR}\right)$, following the manufacturer protocol. The product was amplified via PCR according to the following schedule: $94^{\circ} \mathrm{C}$ for two minutes, 40 cycles of $94{ }^{\circ} \mathrm{C}$ for 30 seconds each, $54{ }^{\circ} \mathrm{C}$ for 30 seconds, $72{ }^{\circ} \mathrm{C}$ for 40 seconds and $72{ }^{\circ} \mathrm{C}$ for four minutes. The PCR product was purified using polyethylene glycol precipitation (PEG) (Schmitz and Riesner, 2006). These samples were sequenced using the Big Dye 3.1 reagent (Life Technologies ${ }^{\circledR}$ ) and 3500 xL automatic sequencer (Life Technologies $®$ ).

Morphological terms used here are from Hansson (2009) and the Neotropical Eulophidae (2018) website.

Abbreviations used in text: DE: distance between eyes, measured across the narrowest part on frons/vertex; DO: diameter of anterior ocellus; HE: height of eye, in frontal view; HW: height of the forewing, measured across the widest part of the wing; LC: length of median carina on propodeum, measured from anterior margin of carina to posterior margin of propodeum; LG: length of the gaster; LM: length of the marginal vein; LP: length of the petiole; LS: length of hind tibial spur; LT: length of hind tarsus; LW: length of the forewing, measured from the base of the marginal vein to the apical margin of the wing; $\mathbf{M M}$ : length of the mesosoma, measured along the median mesosoma, from the pronotal collar carina to posterior margin of the propodeum; MS: malar space; OOL: the distance between eye and posterior ocellus; PM: length of the postmarginal vein; POL: the distance between posterior ocelli; POO: the distance between posterior ocelli and occipital margin; ST: length of the stigmal vein; WC: width of the median carina on the propodeum, measured at equal distance from the anterior and posterior margins of the carina; WG: width of the submedian groove, measured at equal distance from the anterior and posterior margins of median propodeum; WH: width of the head, measured at widest part; WM: width of mouth opening; WP: width of the petiole, measured at the attachment point of the gaster; WT: width of the thorax, measured across the widest part which is usually just in front of the attachment point of the forewing, the "shoulders".

Studied specimens are deposited in the following repositories: Museum of Zoology of the University of São Paulo (MZSP) (São Paulo, São Paulo State, Brazil) and, Instituto Biológico - Coleção de Insetos Entomófagos Oscar Monte (IB-CBE) (Campinas, São Paulo State, Brazil).

\section{Results}

\subsection{Horismenus camobiensis, sp. nov. Salgado-Neto, Costa and Hansson}

Diagnosis. Female: antennal scrobes joining on frontal suture (Figures 2, 3c, 3d); vertex with a sulcus from behind each lateral ocellus to ahead of the ocelli
(Figures 4, 5c); petiole $0.75 \mathrm{x}$ as long as wide. Male: scape white (Figure $4 \mathrm{~b}$ ). Both sexes: mesoscutum with raised and weak reticulation; posterior half of midlobe with engraved and weak reticulation (Figure 5c); notauli indistinct or distinct posteriorly (Figures 3a, 4c, 5c); mesoscutum and scutellum metallic blue with green tinges (Figures 3a, 4c); propodeal callus with two setae, femora, tibiae and tarsi white.

Description. Females: body 1.9-2.2 mm long ( $n=29)$. Males: body $1.6-1.8 \mathrm{~mm}$ long $(n=6)$.

Female. Scape yellowish-white, pedicel and flagellum brown, with metallic blue tinges. Frons and clypeal area metallic blue with green tinges near toruli. Vertex metallic blue with green tinges before lateral ocelli, and metallic green with blue tinges posteriorly. Mesoscutum, scutellum, dorsellum and coxae metallic blue with green tinges; fovea of dorsellum and petiole dark metallic purple. Propodeum with smooth parts metallic blue with green tinges and the reticulate ones metallic dark purple. Femora, tibiae and tarsi yellowish-white. Wings hyaline. Anterior 2/3 of the first tergite of gaster with metallic blue with green tinges, the posterior $1 / 3$ and the remaining tergites metallic dark purple. Clava with two segments weak, 1.1-1.2x as wide as the width of the first flagellomere (Figures 3c, 3d). Frons (just above frontal suture, between antennal scrobes and below level of toruli), corners of the mouth and temple smooth and shiny; remaining parts of frons with raised and strong reticulation; frontal suture $V$-shaped, complete, nearly reaching the eyes; antennal scrobes joining on frontal suture. Vertex with engraved and weak reticulation, with a sulcus coming from behind each lateral ocellus and extending ahead of them, nearly parallel to eyes, until the level of median ocellus; posterior part with a median groove. Occipital margin rounded. Mesoscutum with raised and weak reticulation, posterior half of midlobe with engraved and weak reticulation; notauli indistinct or distinct posteriorly. Scutellum with mesh-rows and engraved and weak reticulation. Dorsellum convex and smooth anteriorly with two foveae connected in the middle. Propodeum smooth and shiny, posterior quarter of submedian grooves and median carina reticulate; propodeal callus with two setae. Coxae smooth and shiny. Forewing speculum closed below, with 13 admarginal setae. First gastral tergite smooth and shiny, with a reticulate band close to posterior margin. Ratios. DE/DO 5.6; WH/DE 2.0; HE/MS/WM 2.8/1.0/1.4; POL/OOL/POO 2.7/0.9/1.0; WH/WT 1.0; LW/LM/HW 1.7/1.1/1.0; PM/ST 1.8; LC/WC 2.6; WG/ WC 0.7; LS/LT 0.19; LP/WP 0.7; MM/LG 0.8.

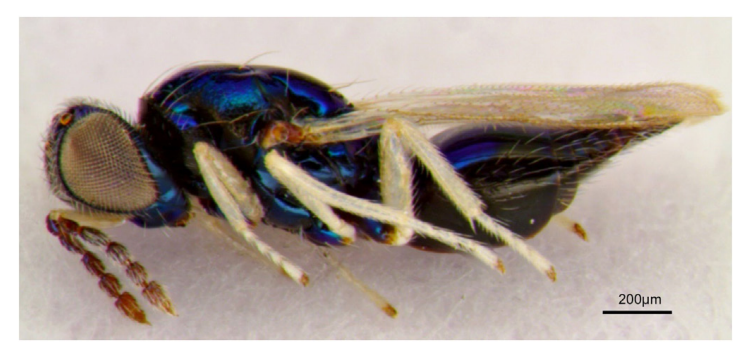

Figure 2. Horismenus camobiensis sp. nov. Habitus, holotype female. 

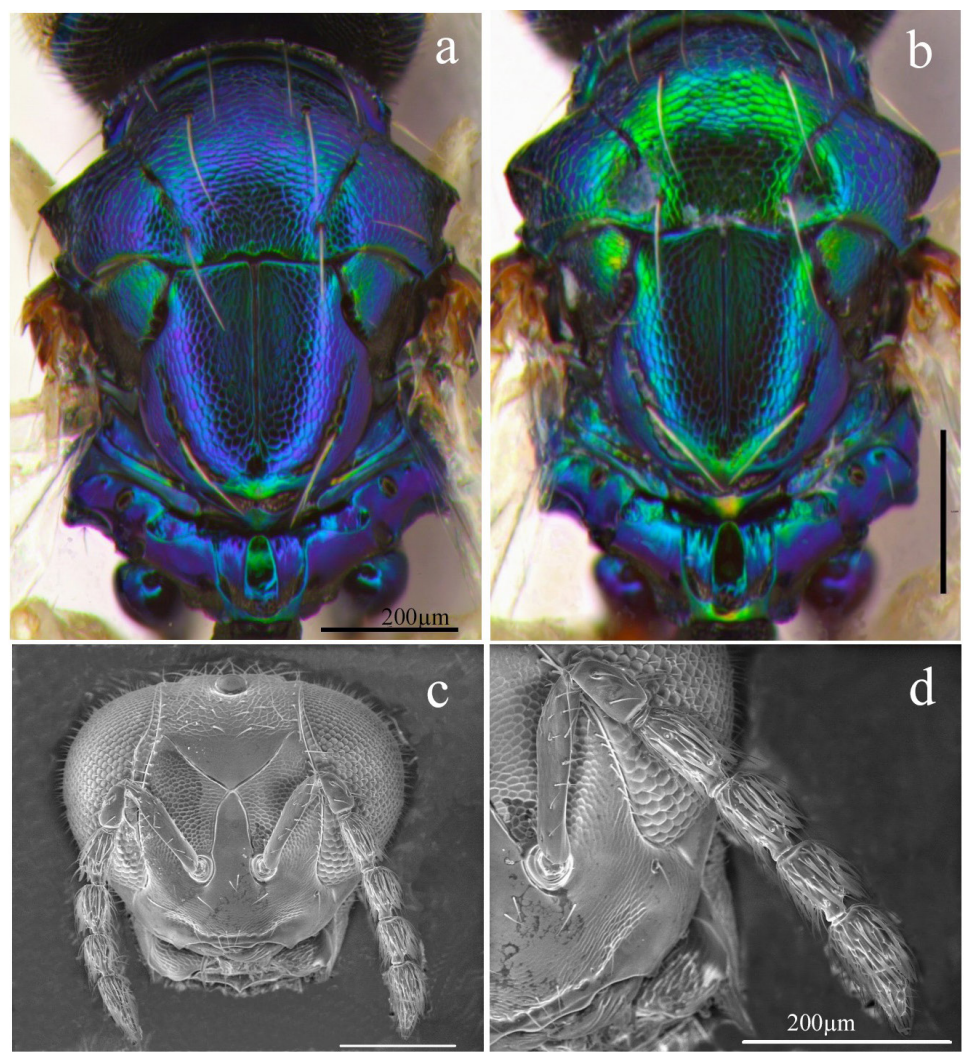

Figure 3. Horismenus camobiensis sp. nov.: thoracic dorsum, female (a); thoracic dorsum, male (b); head, frontal, female (c); antenna, lateral, female (d).
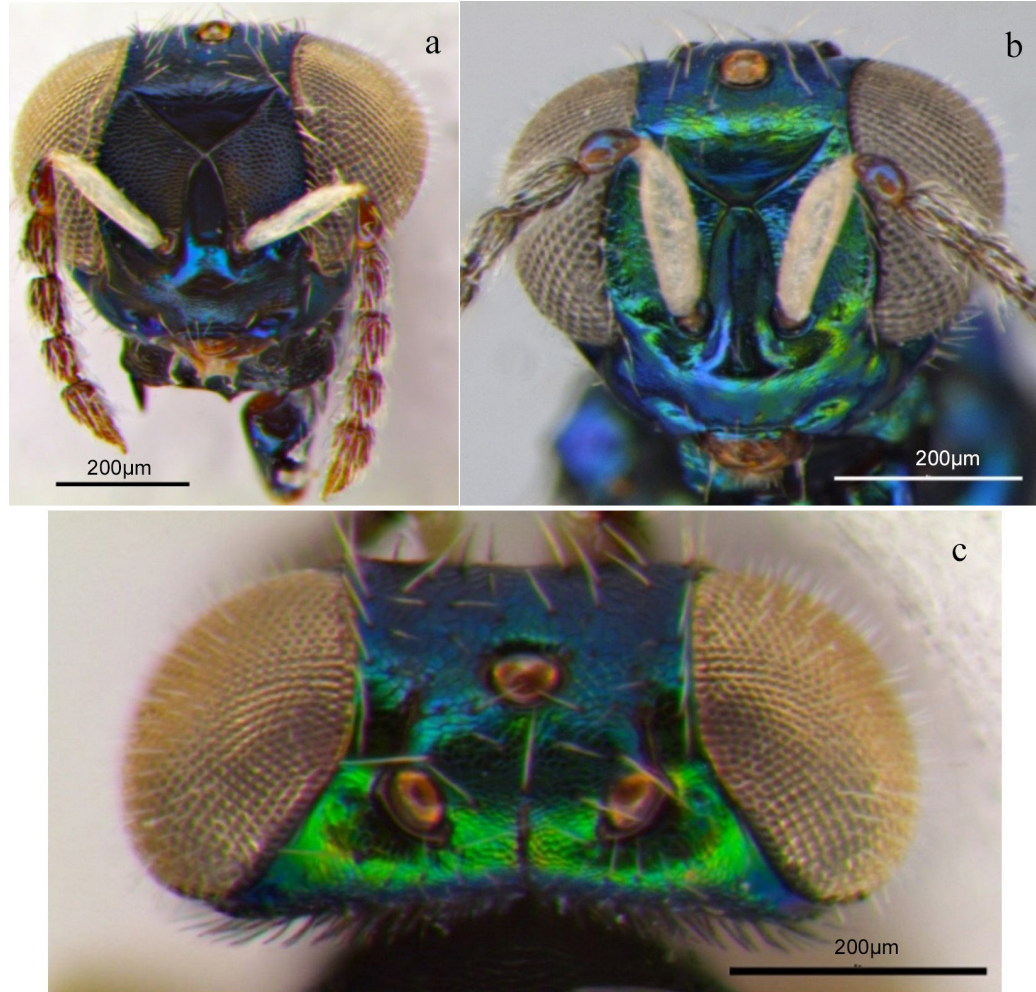

Figure 4. Horismenus camobiensis sp. nov.: head, frontal, female (a); head, frontal, male (b); vertex, dorsal, female (c). 
Male. Similar to female, except as follow: frons bright metallic green with blue tinges. Vertex bright metallic green with blue and golden tinges. Mesoscutum bright metallic green with blue tinges. Scutellum bright metallic green with blue tinges more intense than in the mesoscutum (Figure 3b). Antenna as in Figure 5a. Scape: 2.7x as long as it is wide. Antennal scrobes joining frontal suture separately (Figure 5b). Ratios. HE/MS/WM 2.7/1.0/1.6; LP/ WP 0.8; MM/LG 1.1.

Type material. Holotype female (MZSP), card mounted, with label "BRASIL-RS-Camobi, [29 42' 19" S, 53 42' 57" W], Ex cocoon mass of Cotesia invirae, col. G. Salgado-Neto, 10.III.2006" (MZSP 62028). Paratypes. Same data as for holotype; twenty-two females and three males (MZSP 62028-62053); seven females and three males (IB-CBE 2713-2732).

Biology. Hyperparasitoid. The studied specimens were reared from cocoons of $C$. invirae obtained from 0 . invirae caterpillars.

Distribution. Santa Maria (Camobi), Rio Grande do Sul state, Brazil.

Etymology. The specific epithet is a reference to the type locality, Camobi, Rio Grande do Sul state, Brazil; "camobiensis" originates in the native Guarani language, where $k a ̃ m o b i=k \tilde{a}$ (breast) and mobi (nipple), in reference to the shape of the hills of the region, is associated with the Latin suffix ensis (origin).

Remarks. Females run to subkey $\mathrm{S}$ using the key in Hansson (2009), Here, H. camobiensis would run to couplet 18 , where, because of the variable condition of the posterior notauli, one should run both ways. If the mesoscutum has narrow and distinct notauli in the posterior half, then $H$. camobiensis would run to $H$. iangauldi in couplet 20; but in $H$. camobiensis sp. nov. has: a. the midlobe of the mesoscutum with engraved reticulation on its posterior part (vs. raised reticulation in $H$. iangauldi); b. scutellum with strongly engraved reticulation (vs. weakly engraved reticulation in $\mathrm{H}$. iangauldi); c. female with scrobes joining on the frontal suture (vs. females with scrobes joining separately on the frontal suture in $\mathrm{H}$. iangauldi); $\mathrm{d}$. female vertex with a sulcus from behind each lateral ocellus to ahead of the ocelli (vs. this sulcus is absent in H. iangauldi), and e. male scape completely white (vs. completely brown in $H$. iangauldi). If the notauli are indistinct posteriorly, then $H$. camobiensis would run to $H$. amadeus in couplet 34 , and in this case the differences between these two species are: a; antennal scrobes joining on the frontal suture (vs. the antennal scrobes join the frontal suture separately in $H$. amadeus); b. female frons with metallic blue with green tinges near the toruli (vs. metallic dark purple in $H$. amadeus); c. the female petiole $0.7 \mathrm{x}$ as long as wide (vs. 1.4-2.0x as long as wide in H. amadeus); and d. female vertex with a sulcus coming from behind each lateral ocellus and extending ahead of the ocelli (vs. this sulcus is absent in H. amadeus).

Horismenus opsiphanis Schrottky, 1909 also uses C. invirae as host (Salgado-Neto and Di Mare, 2010). However, $H$. opsiphanis can readily be separate from $H$. camobiensis sp. nov. by: a. the first tergite of the gaster in has round punctures or weak reticulation in the
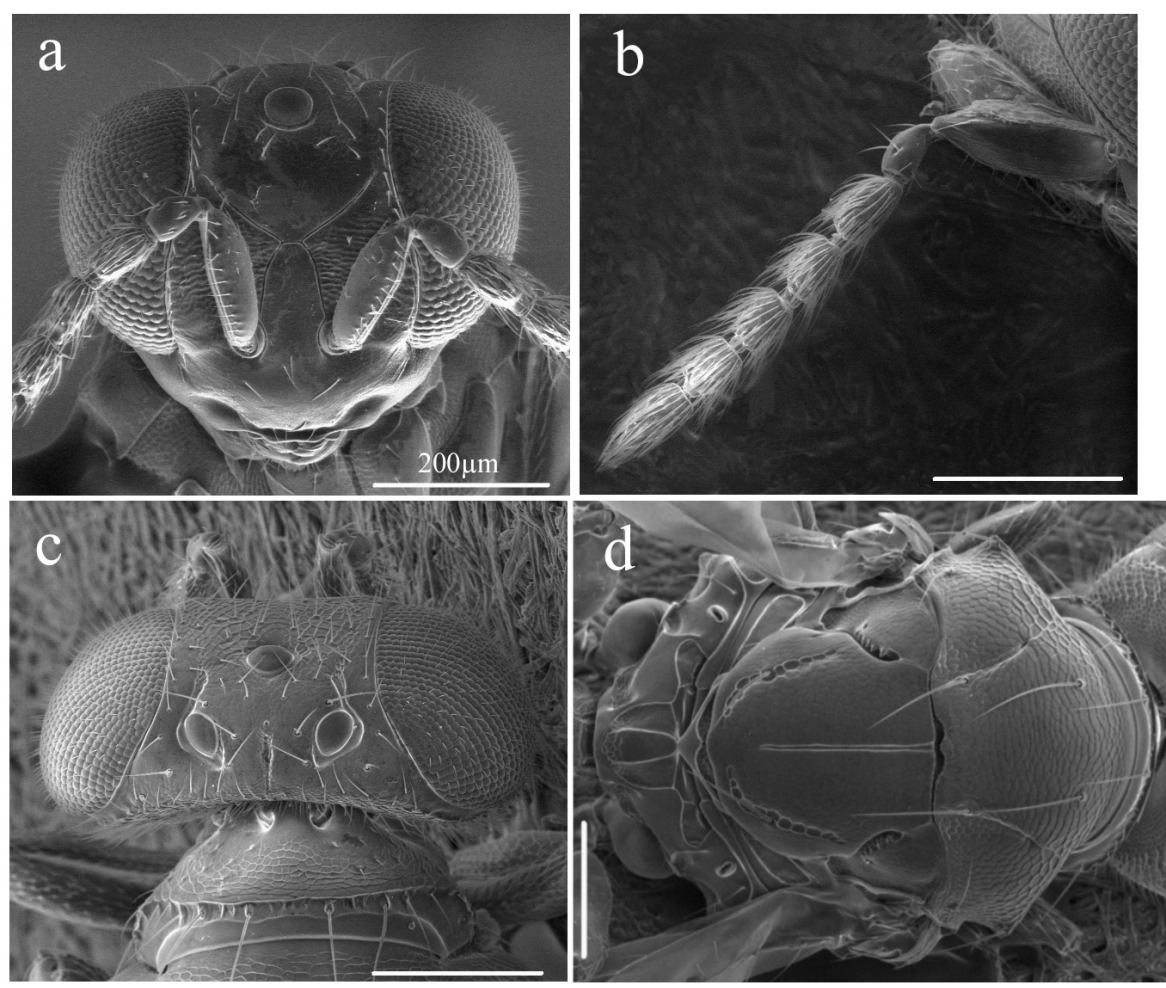

Figure 5. Horismenus camobiensis sp. nov.: head, frontal, male (a); antenna, lateral, male (b); vertex, dorsal, female (c); mesosoma, dorsal, female (d). 

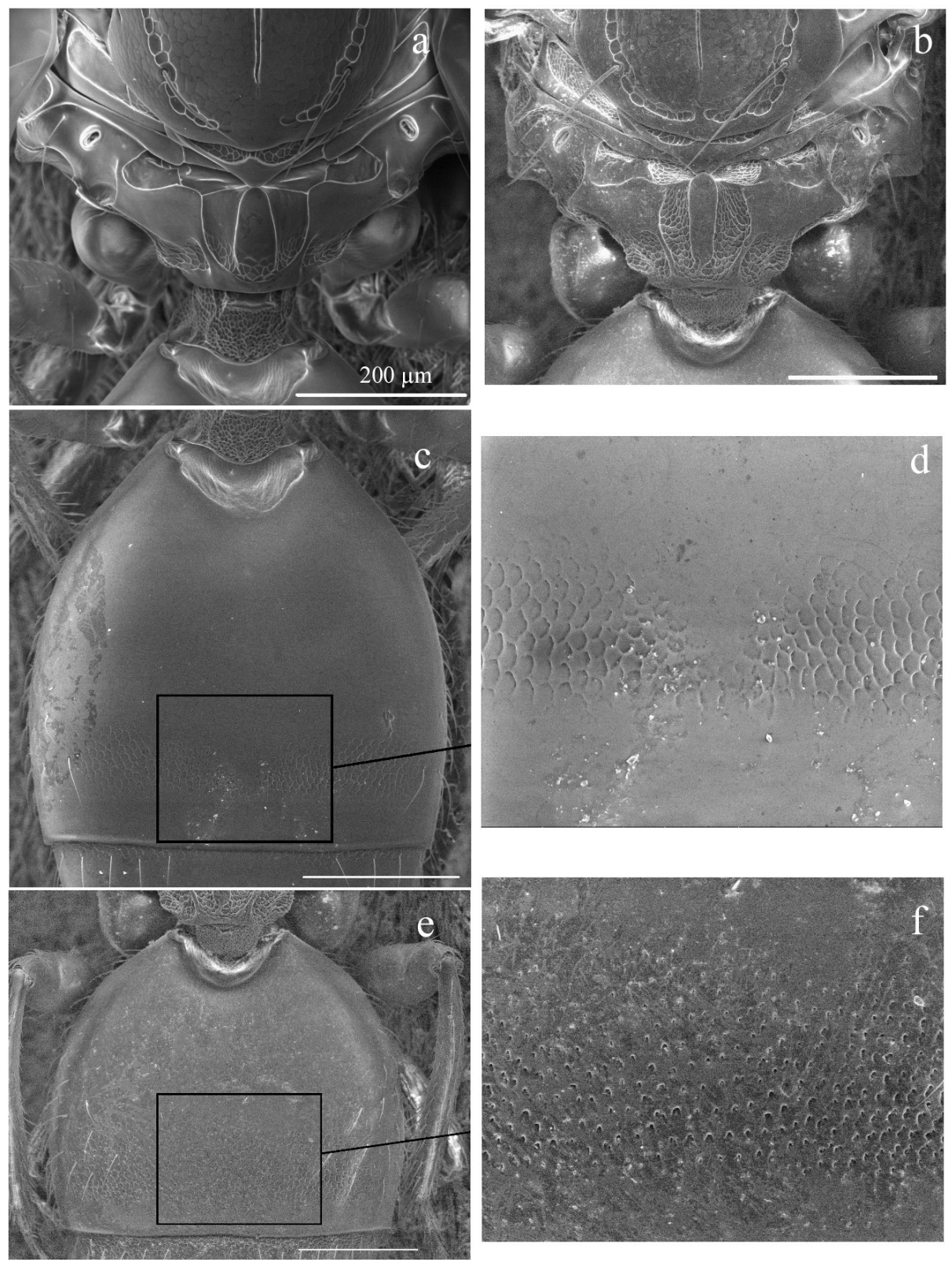

Figure 6. Horismenus spp., female: Horismenus camobiensis sp. nov., propodeum, dorsal (a); Horismenus opsiphanis, propodeum, dorsal (b); Horismenus camobiensis sp. nov., first gastral tergite, dorsal (c); Horismenus camobiensis sp. nov., first gastral tergite, detail, dorsal (d); Horismenus opsiphanis, first gastral tergite, dorsal (e); Horismenus opsiphanis, first gastral tergite, detail, dorsal (f).

posteromedial third H. opsiphanis, and so it runs up or down to subkey G or R, respectively (Figures 6d-f); but in $H$. camobiensis sp. nov., this area is clearly reticulate, what leads to key $S$ (Figures 6b, 6c). Additional differences are: $H$. opsiphanis has a propodeum with the median carina long and narrow, WG/WC 1.3 , and the submedian grooves completely reticulate, with strong reticulation (Hansson, 2009) (Figure 6a); H. camobiensis sp. nov. has a propodeum with a stout median carina, WG/WC 2.6, and the submedian grooves only reticulate in the posterior third (Figure 5d). In addition, the scape of the male is white in $\mathrm{H}$. camobiensis sp. nov. and dark brown with metallic tinges in $H$. opsiphanis. The sequence of $H$. opsiphanis is deposited in the GenBank with the number MK455797.

\section{Acknowledgements}

Thanks to the Brazilian agencies Conselho Nacional de Desenvolvimento Científico e Tecnológico (CNPq), Coordenação de Aperfeiçoamento de Pessoal de Nível Superior (CAPES), Instituto Nacional de Ciência e Tecnologia dos Hymenoptera Parasitoides da Região Sudeste Brasileira (INCT-Hympar Sudeste) and Programa Cooperativo sobre Proteção Florestal 
(PROTEF) do Instituto de Pesquisas e Estudos Florestais (IPEF) for their support. To Dr. Luciana Bueno dos Reis Fernandes (Universidade Federal de São Carlos, São Paulo, Brasil), for the scanning electron micrographs of Horismenus camobiensis, and to Dr. Ricardo Harakava (Instituto Biológico, São Paulo, SP, Brazil) for molecular analyses of the COI. David Michael Miller, a professional editor and proofreader and native English speaking, has reviewed and edited this article for structure, grammar, punctuation, spelling, word choice, and readability.

\section{References}

ASHMEAD, W.H., 1904. Classification of the Chalcid Flies or the Superfamily Chalcidoidea, with descriptions of new species in the Carnegie Museum. Publications of the Carnegie Museum, vol. 1, no. 4, pp. 1-551.

CAMERON, P., 1884. Hymenoptera (Families TenthredinidaeChrysididae). In: F.D. GODDMAN and D. SALVIN, eds. Biologia centrali-americana: Insecta Hymenoptera. London: Taylor \& Francis, vol. 1, 487 p.

DELVARE, G., HEIMPEL, G.E., BAUR, H., CHADEE, D.D., MARTINEZ, R. and KNUTIE, S.A., 2017. Description of Brachymeria philornisae sp. n. (Hymenoptera: Chalcididae), a parasitoid of the bird parasite Philornis trinitensis (Diptera: Muscidae) in Tobago, with a review of the sibling species. Zootaxa, vol. 4242, no. 1, pp. 34-60. http://dx.doi.org/10.11646/zootaxa.4242.1.2. PMid:28610193.

FABRICIUS, J. C., 1787. Mantissa insectorum sistens eorum species nuper detectas adiectis characteribus, genericis, differentiis, specificis, emendationibus, observationibus. Hafniae: Impensis C.G. Proft, vol. 1, 382 p. http://dx.doi.org/10.5962/bhl.title.36471.

FERREIRA, J., LIMA, M., SANTANA, D. and MOURA, J., 1998. Pragas do coqueiro. In: R. BRAGA-SOBRINHO, J.E. CARDOSO and F.C.O. FREIRE, eds. Pragas de fruteiras tropicais de importância agroindustrial. Brasília: Embrapa-SPI; Fortaleza: EmbrapaCNPAT, pp. 81-118.

GUSMÃO, F., HARAKAVA, R. and CAMPOS, A., 2010. Fire-ants of the Solenopsis saevissima species-group (Hymenoptera: Formicidae) nesting in parks in the city of São Paulo: identification based on mtDNA sequences and morphological characters. Sociobiology, vol. 56, pp. 353-362.

HANSSON, C., 2009. Eulophidae of Costa Rica (Hymenoptera: Chalcidoidea), 3. The genus Horismenus. Memoirs of the American Entomological Institute, vol. 82, pp. 1-916.

HANSSON, C., PÁDUA, D., SCHOENINGER, K., AGUDELO, A. and OLIVEIRA, M., 2014. A new species of Horismenus Walker (Hymenoptera, Eulophidae) from ootheca of Liturgusa Saussure (Mantodea, Liturgusidae) from Central Amazonas, Brazil. Journal of Hymenoptera Research, vol. 37, pp. 53-60. http:// dx.doi.org/10.3897/jhr.37.6729.

KERR, P., FISHER, E. and BUFFINGTON, M., 2008. Dome lighting for insect imaging under a microscope. American Entomologist, vol. 54, no. 4, pp. 198-200. http://dx.doi.org/10.1093/ae/54.4.198.

LEPESME, P., 1947. Les insectes des palmiers. Paris: Paul Lechevalier, $904 \mathrm{p}$.

MORALES-SILVA, T., MAIA, L.F., MARTINS, A.L. and MODESTOZAMPIERON, S.L., 2019. Herbivore, parasitoid and hyperparasitoid insects associated with fruits and seeds of Enterolobium contortisiliquum (Vell.) Morong (Fabaceae). Brazilian Journal of Biology = Revista Brasileira de Biologia, vol. 79, no. 3, pp. 369-376. http://dx.doi.org/10.1590/1519-6984.170105. PMid:30231136.

NEOTROPICAL EULOPHIDAE [online], 2018 [viewed 18 October 2018]. Available from: http://neotropicaleulophidae.com/
NOYES, J., 2018 [viewed 18 October 2018]. Universal Chalcidoidea Database [online]. Available from: http://www.nhm.ac.uk/ chalcidoids

PIKART, T., COSTA, V., HANSSON, C., ZANUNCIO, J. and SERRÃO, J., 2015. Three new species of Horismenus Walker (Hymenoptera: Eulophidae) associated with seed pods of Pithecellobium dulce (Fabaceae).Zootaxa, vol. 3994, no. 4, pp. 565-578. http://dx.doi. org/10.11646/zootaxa.3994.4.5. PMid:26250291.

SALGADO-NETO, G., 2013. Aspects of the biology of Cotesia alius (Muesebeck, 1958)(Hymenoptera: Braconidae: Microgastrinae) on Opsiphanes invirae amplificatus Stichel (Lepidoptera: Nymphalidae) in Rio Grande do Sul, Brazil. Estudos Biológicos, vol. 35, no. 84, pp. 35-41. http://dx.doi.org/10.7213/estud.biol.7854.

SALGADO-NETO, G. and DI MARE, R., 2010. Hiperparasitóides em Cotesia alius (Mues.) (Hymenoptera; Braconidae) no estado do Rio Grande do Sul, Brasil. Magistra, vol. 22, pp. 210-212.

SALGADO-NETO, G., VÁSQUEZ, C.A.N., MAX, D. and WHITFIELD, J., 2021. Cotesia cassina, sp. nov., from southwestern Colombia: a new gregarious microgastrinae wasp (Hymenoptera: Braconidae) reared from the pest species Opsiphanes cassina Felder \& Felder (Lepidoptera: Nymphalidae) feeding on Elaeis oil palm trees (Arecaceae).ZooKeys, vol. 1061, pp. 11-22. http:// dx.doi.org/10.3897/zookeys.1061.67458. PMid:34720610.

SALGADO-NETO, G., WHITFIELD, J. and GARCIA, F., 2019. Cotesia invirae, sp. nov., from South Brazil: a new gregarious microgastrinae wasp (Hymenoptera: Braconidae) reared from Opsiphanes invirae (Nymphalidae) feeding on palms. Revista Brasileira de Entomologia, vol. 63, no. 2, pp. 101-194. http:// dx.doi.org/10.1016/j.rbe.2019.02.003.

SCHMITZ, A. and RIESNER, D., 2006. Purification of nucleic acids by selective precipitation with polyethylene glycol 6000 . Analytical Biochemistry, vol. 354, no. 2, pp. 311-313. http:// dx.doi.org/10.1016/j.ab.2006.03.014. PMid:16725102.

SEFER, E., 1961. Catálogo dos insetos que atacam as plantas cultivadas da Amazônia. Boletim Técnico do Instituto Agronômico Norte, vol. 43, pp. 23-53.

SHAW, M.R. and HUDDLESTON, T., 1991. Classification and biology of braconid wasps (Hymenoptera, Braconidae): handbooks for the Identification of British Insects. Royal Entomological Society of London, vol. 7, pp. 1-126.

SILVA, A., GONÇALVES, C., GALVÃO, D., GONÇALVES, A., GOMES, J., SILVA, M. and SIMONI, L., 1968. Quarto catálogo dos insetos que vivem nas plantas do Brasil: seus parasitas e predadores. Rio de Janeiro: Ministério da Agricultura, tomo 1, part. 2, 622 p.

TAMURA, K. and NEI, M., 1993. Estimation of the number of nucleotide substitutions in the control region of mitochondrial DNA in humans and chimpanzees. Molecular Biology and Evolution, vol. 10, no. 3, pp. 512-526. PMid:8336541.

TAMURA, K., PETERSON, D., PETERSON, N., STECHER, G., NEI, M. and KUMAR, S., 2011. MEGA5: molecular evolutionary genetics analysis using maximum likelihood, evolutionary distance, and maximum parsimony methods. Molecular Biology and Evolution, vol. 28, no. 10, pp. 2731-2739. http://dx.doi.org/10.1093/molbev/ msr121. PMid:21546353.

TOWNSEND, C.H.T., 1939. Manual of Myiology in twelve parts. Itaquaquecetuba: Townsend \& Filhos, pt. VII, $434 \mathrm{p}$.

WIEDEMANN, C.R.W., 1830. Aussereuropäische zweiflügelige Insekten. Hamm: Schulzischen Buchhandlung, vol. 2, 684 p.

VAN DER WULP, F.M., 1890. Diptera. In: F.D. GODMAN and O. SALVIN, eds. Biologia Centrali - Americana. London, vol. 2, 489 p.

YU, D.S.K., VAN ACHTERBERG, C. and HORSTMANN, K., 2016 [viewed 18 October 2018]. Taxapad, Ichneumonoidea 2015 [online]. Ottawa: Taxapad. Available from: http://www.taxapad.com 